\title{
The influence of physiotherapy on blood pressure in children and adolescents with respiratory tract diseases
}

\author{
IWONA PIROGOWICZ ${ }^{1, A-G}$, MACIEJ ORNAT ${ }^{2, A-E}$, BARTOSZ JERCZAK ${ }^{2, A, B, D-F}$, \\ KRZYSZTOF PACHOŁEK ${ }^{2, B, D-F}$, PAULINA DOMEREDZKA ${ }^{2, B, C, E}$, ŁUKASZ GOJNY2, E
}

${ }^{1}$ Department and Clinic of Geriatrics, Wroclaw Medical University

${ }^{2}$ Student Scientific Organization for Health Promotion and Disease Prevention at the Department and Clinic of Geriatrics, Wroclaw Medical University

A - Study Design, B - Data Collection, C - Statistical Analysis, D - Data Interpretation, E - Manuscript Preparation, F - Literature Search, $\mathbf{G}-$ Funds Collection

\begin{abstract}
Summary Background. Arterial hypertension is an essential, often underestimated medical problem among school youth. Maintaining a low blood pressure (BP) in children should be an important point of pediatric preventive healthcare.

Objectives. In our study, we considered the influence of physiotherapy on the blood pressure level in a group of 233 children aged from 8 to 15 years taking part in a rehabilitation camp for children in the Szklarska Poreba mountain resort (95 children in 2014 and 138 children in 2015).

Material and methods. The children selected for the study suffered from asthma or recurrent respiratory infections. Measurements were made before and after physiotherapy. During the camp, the children were examined two times in 2014 and three times in 2015. The database created contained 1,208 scores of systolic and diastolic BP. The control group consisted of 50 children whose BP was measured in the same hours, but during the weekend, which was free of physiotherapy. Moreover, the values of heart rate (HR) during the first measurement were recorded, both in 2014 and 2015.

Results. Systolic BP after physiotherapy was significantly lower than before. This result was achieved in every five measuring sessions. In the control group, BP measured in the afternoon was higher than in the morning. The values of HR were not significantly different. The values of BP before and after physiotherapy between children treated with inhaled glucocorticoids and treated without glucocorticoid were not statistically significant.

Conclusions. Our studies showed that morning exercise can significantly reduce blood pressure in children throughout the day, even in those who were treated with inhaled glucocorticoids.
\end{abstract}

Key words: children, blood pressure, hypertension, exercise, adolescents.

Pirogowicz I, Ornat M, Jerczak B, Pachołek K, Domeredzka P, Gojny Ł. The influence of physiotherapy on blood pressure in children and adolescents with respiratory tract diseases. Fam Med Prim Care Rev 2017; 19(1): 54-58, doi: 10.5114/fmpcr.2017.65092.

\section{Background}

Arterial hypertension is an essential, often underestimated medical problem concerning $3-3.5 \%$ of children up to the age of 18 years. The size of the problem is greater among adolescents and reaches $10 \%$ in this age group [1]. Primary hypertension is the most common type of arterial hypertension among schoolchildren. It is often associated with being overweight and metabolic disorders [2]. According to the results of the clinical project OLAF (OLAF - Development of blood pressure standards for the population of children and adolescents in Poland), which was performed in 2007-2009 in Poland, the conclusion can be drawn that the problem of hypertension is connected with the 'obesity epidemic'. This is similar to the situation in other European countries $[3,4]$. According to other research, children with higher blood pressure (BP) are in a risk group for developing a metabolic syndrome in the future $[5,6]$. These facts show how important regular blood pressure monitoring is, as well as prevention programs. Broadly defined physical activity should be considered not only as a remedy for obesity, but also as a method for reducing blood pressure (PEH - post exercise hypotension). In this study, the influence of physiotherapy on the blood pressure level in a group of 233 children aged from 8 to 15 years has been considered.

\section{Objectives}

The aim of our research was to check the influence of rehabilitation care, which consisted of cardio exercises and physiotherapy, on blood pressure among children with respiratory tract disorders during a rehabilitation camp in the Szklarska Poreba mountain resort (Poland).

\section{Material and methods}

BP measurements were the elements of a medical examination which was part of medical care during the rehabilitation treatment camp, funded by the Agricultural Social Insurance Fund (KRUS). Our research was performed during a summer rehabilitation camp for children with respiratory tract disorders in the Szklarska Poreba mountain resort. During this camp, children attended physiotherapy, which consisted of: classic massage, aerobics, Nordic walking, individual and group gymnastics, swimming pool classes, mountain hiking, karate classes and salt baths. Every child performed cardio exercise, such as group gymnastics, aerobics and some form of physiotherapy (massage, corrective gymnastics or salt baths) every day except the weekend (which was set aside for other activities, i.e. sightseeing, visiting museums, etc.). These activities were carried out by skilled 
and qualified personnel. The cardio exercises were provided in separate groups for boys and girls and at different levels. The difficulty of the exercises was adjusted in such a manner that all the children, no matter how fit they were, managed to attend them. Children with very high BP in the morning reported to a doctor who decided, after an examination, whether or not they could attend the exercises. BP results were collected during two camps in July 2014 and July 2015, both of which were attended by 240 children. In view of the large number of children, only 233 of them, randomly selected, were measured, and 48 of them were treated with inhaled glucocorticoids (95 in July 2014 and 138 in July 2015). In July 2014, BP was measured twice, and three times in July 2015. BP was measured two times a day; the first measurement was made in the morning (between 7 a.m. -8 a.m.) before any exercises. The second measurement was made in the afternoon, a minimum of 15 minutes after the last physiotherapy treatment planned for that day (between 2 p.m. -4 p.m. every group had a different schedule). Blood pressure was measured on five occasions twice a day: the $1^{\text {st }}$ and $2^{\text {nd }}$ measurements were made in July 2014 among 95 children; after 3 days and 2 weeks of activities, respectively (190 measurements of BP before and after physiotherapy, total od 380 values of BP in 2014). The $3^{\text {rd }}, 4^{\text {th }}$ and $5^{\text {th }}$ measurements were made in July 2015 among 138 children after 3 days, 1 week and 2 weeks of activities, respectively (414 measurements of BP before and after physiotherapy, total of 828 values of BP in 2015). The age of children in each measurement was different. Total database: 1,208 values of BP.

Moreover, heart rate was recorded during the $1^{\text {st }}$ and $3^{\text {rd }}$ measurement (in view of the large number of children and limited number of researchers, HR was measured only at the beginning of the camp after 3 days of activities, both in 2014 and 2015). The control group consisted of 50 children whose BP was measured in the same hours, but during the weekend, which was free of physiotherapy.

BP was measured in a seated position with the use of a mercury sphygmomanometer (with different cuff sizes proper to the diameter of the arm) and a stethoscope. The database was made using Microsoft Excel 2014, and statistical analysis was performed with the Statistica program by StatSoft Inc.

\section{Results}

The average SBP from all measurements before physiotherapy treatment was $110.5 \mathrm{~mm} \mathrm{Hg}$ and was higher than the average SBP from measurements made after that treatment, which reached $105.5 \mathrm{~mm} \mathrm{Hg}$. The highest single values of systole and diastole BP before physiotherapy treatment were, respectively, 175 and $106 \mathrm{~mm} \mathrm{Hg}$, whereas the highest values of systole and diastole BP after that treatment were 155 and $103 \mathrm{~mm} \mathrm{Hg}$ (Table 1).

\begin{tabular}{|c|c|c|c|c|}
\hline \multirow[t]{2}{*}{ Characteristic } & \multicolumn{2}{|c|}{ Before physiotherapy } & \multicolumn{2}{|c|}{ After physiotherapy } \\
\hline & SBP & DBP & SBP & DBP \\
\hline Mean & 110.5 & 66.6 & 105.5 & 65.3 \\
\hline Highest value & 175 & 106 & 155 & 103 \\
\hline Lowest value & 60 & 40 & 65 & 40 \\
\hline Standard deviation & 13.01 & 9.59 & 13.04 & 10.31 \\
\hline
\end{tabular}

The average values of SBP with standard deviation in 5 groups of measurements made in years 2014-2015 are presented in the graph (Figure 1). The average values of SBP after physiotherapy treatment were statistically significant and lower than before therapy in all 5 groups of measurements (Table 2 ).
The average values of diastolic blood pressure (DBP) were statistically significant and lower after physiotherapy only in group number 4. Other average values of DBP were not significantly different before and after physiotherapy.

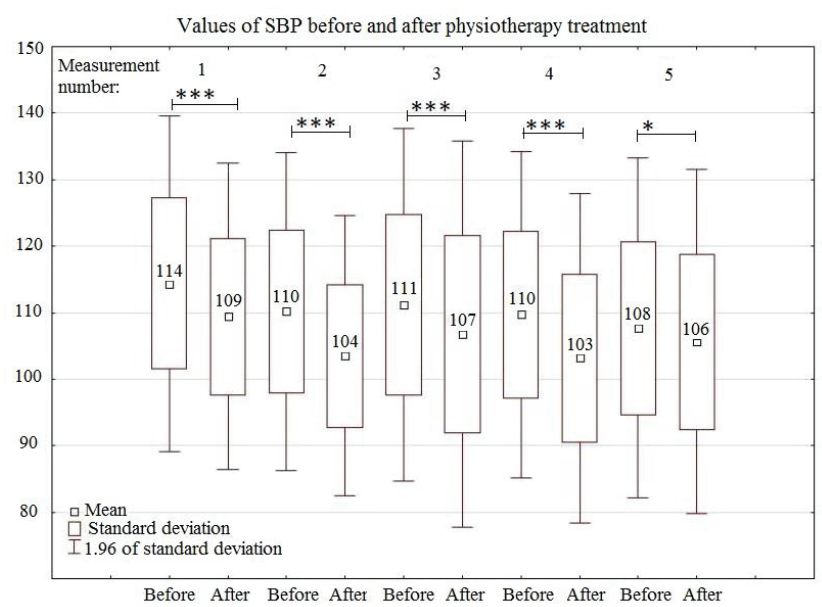

Figure 1. Values of SBP from 5 groups of measurements made in the years 2014-2015

$* * * p<0.001, * p<0.05$

\begin{tabular}{|c|c|c|c|c|}
\hline $\begin{array}{l}\text { Measure- } \\
\text { ment }\end{array}$ & $\begin{array}{l}\text { BP before } \\
\text { physiotherapy }\end{array}$ & vs. & $\begin{array}{l}\text { BP after } \\
\text { physiotherapy }\end{array}$ & $p$-value \\
\hline \multirow[t]{2}{*}{1} & systolic & vs. & systolic & $<0.001$ \\
\hline & diastolic & vs. & diastolic & $>0.05$ \\
\hline \multirow[t]{2}{*}{2} & systolic & vs. & systolic & $<0.001$ \\
\hline & diastolic & vs. & \begin{tabular}{|l|} 
diastolic \\
\end{tabular} & $>0.05$ \\
\hline \multirow[t]{2}{*}{3} & systolic & vs. & systolic & $<0.001$ \\
\hline & diastolic & vs. & diastolic & $>0.05$ \\
\hline \multirow[t]{2}{*}{4} & systolic & vs. & systolic & $<0.001$ \\
\hline & diastolic & vs. & diastolic & $<0.001$ \\
\hline \multirow[t]{2}{*}{5} & systolic & vs. & systolic & $<0.05$ \\
\hline & diastolic & vs. & diastolic & $>0.05$ \\
\hline
\end{tabular}

Table 3. Statistical dependences of BP values before

and after physiotherapy treatment among age groups; 8-15 year-old children

\begin{tabular}{|l|l|l|l|l|}
\hline $\begin{array}{l}\text { Age } \\
\text { [years] }\end{array}$ & $\begin{array}{l}\text { BP before } \\
\text { physiotherapy }\end{array}$ & vs. & $\begin{array}{l}\text { BP after } \\
\text { physiotherapy }\end{array}$ & $p$-value \\
\hline \multirow{2}{*}{8} & systolic & vs. & systolic & 0.01 \\
\cline { 2 - 5 } & diastolic & vs. & diastolic & $<0.05$ \\
\hline \multirow{2}{*}{10} & systolic & vs. & systolic & $>0.05$ \\
\cline { 2 - 5 } & diastolic & vs. & diastolic & $>0.05$ \\
\hline \multirow{2}{*}{11} & systolic & vs. & systolic & $<0.01$ \\
\cline { 2 - 5 } & diastolic & vs. & diastolic & $>0.05$ \\
\hline \multirow{3}{*}{12} & systolic & vs. & systolic & $<0.001$ \\
\cline { 2 - 5 } & diastolic & vs. & diastolic & $>0.05$ \\
\hline \multirow{2}{*}{13} & systolic & vs. & systolic & $<0.001$ \\
\cline { 2 - 5 } & diastolic & vs. & diastolic & $>0.05$ \\
\hline \multirow{2}{*}{14} & systolic & vs. & systolic & $<0.001$ \\
\cline { 2 - 5 } & diastolic & vs. & diastolic & $>0.05$ \\
\hline \multirow{2}{*}{15} & systolic & vs. & systolic & $<0.001$ \\
\cline { 2 - 5 } & diastolic & vs. & diastolic & $>0.05$ \\
\cline { 2 - 5 } & systolic & vs. & systolic & $<0.05$ \\
\cline { 2 - 5 } & diastolic & vs. & diastolic & $<0.05$ \\
\hline
\end{tabular}


Analysis of SBP in the age group of 8 to 15 years revealed that the average values of SBP after physiotherapy treatment were statistically significant and lower than before therapy in all age groups (except 9 year-olds). Furthermore, the mean values of DBP in the youngest and the oldest age groups were lower after physiotherapy. Other average values of BP were not statistically different before and after physiotherapy (Table 3 ).

A control measurement of BP among the children who did not take part in physiotherapy treatment on the day of measurement was made in the morning and afternoon (typical time for correct research measurements). The average values of SBP and mean arterial pressure (MAP) were, in contrast to research measurements, significantly higher in the afternoon than in the morning (Figure 2). The mean values of DBP were not of statistical significance in the morning and afternoon.

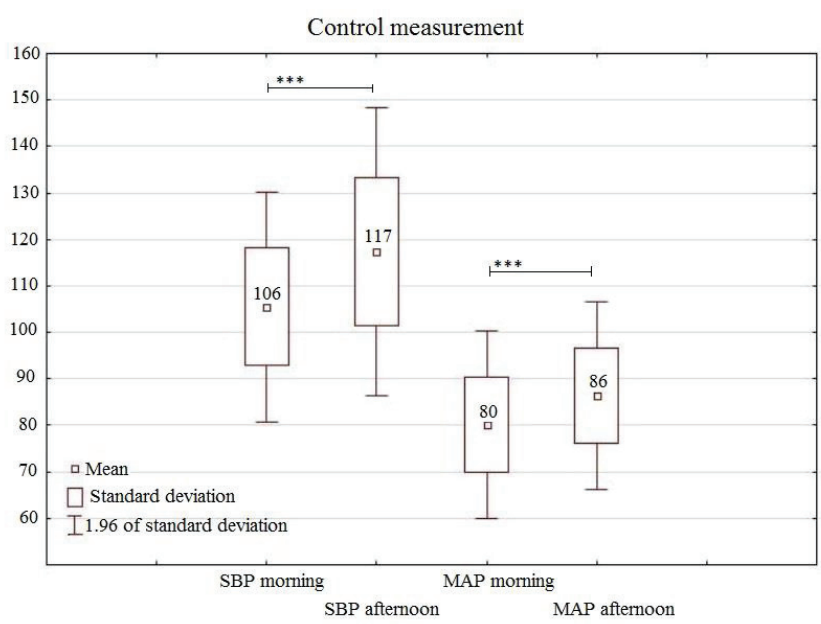

Figure 2. Mean values of SBP in the morning and in the afternoon $* * * p<0.001$.

Analysis of MAP showed that the average MAP values after physiotherapy treatment in the following age groups: 8,11 and 13-15 year-olds, were statistically significant and lower than before therapy. In other age groups, the differences between average MAP values before and after physiotherapy were not statistically significant. In the control group, the average MAP value in the afternoon was statistically significant and higher than in the evening (Table 4).

\begin{tabular}{l}
$\begin{array}{l}\text { Table 4. Statistical dependences of MAP values before and after } \\
\text { physiotherapy treatment among age groups: 8-15 year-old } \\
\text { children and in the control group. Measurements made in the } \\
\text { years 2014-2015 }\end{array}$ \\
\hline \begin{tabular}{l|l|l|} 
Research group & Control group \\
\hline $\begin{array}{l}\text { Age } \\
\text { [years] }\end{array}$ & $\begin{array}{l}\text { MAP before physiotherapy } \\
\text { vs. } \\
\text { MAP after physiotherapy }\end{array}$ & $\begin{array}{l}\text { MAP in evening } \\
\text { vs. } \\
\text { MAP in afternoon }\end{array}$ \\
\hline 8 & $<0.01$ & $<0.001^{*}$ \\
\hline 9 & $>0.05$ & \\
\hline 10 & $>0.05$ & \\
\hline 11 & $<0,01$ & \\
\hline 12 & $>0.5$ & \\
\hline 13 & $<0.05$ & \\
\hline 14 & $<0.05$ & \\
\hline 15 & $<0.001$ & \\
\hline
\end{tabular}
\end{tabular}

* Values after physiotherapy were higher than before.

The values of heart rate (HR) before and after physiotherapy treatment among male and female children were not of statistical importance. The average values of HR were similar before and after physiotherapy (Figure 3).



Figure 3. Values of HR from $1^{\text {st }}$ and $3^{\text {rd }}$ measurement made in the years 2014 and 2015, respectively. $1: p=0.11 ; 2: p=0.58$

The values of SBP and DBP before physiotherapy between children treated with inhaled glucocorticoids and those treated without glucocorticoid were of no statistically significant difference $(p>0.05)$. The values of SBP and DBP between both groups of children after physiotherapy were also of no statistically significant difference $(p>0.05)$ (Table 5). The values of SBP among children treated with inhaled glucocorticoids were statistically significant and lower after physiotherapy than before, both in 2014 and $2015(p<0.001)$ (Figure 4). DBP before and after physiotherapy was not statistically different before and after physiotherapy among this group of children.

Table 5. Statistical dependences of BP values before and after physiotherapy treatment among children treated with or without inhaled glucocorticoid

\begin{tabular}{|l|l|l|l|}
\hline $\begin{array}{l}\text { Treated with inhaled } \\
\text { glucocorticoid }\end{array}$ & vs. & $\begin{array}{l}\text { Treated without in- } \\
\text { haled glucocorticoid }\end{array}$ & $p$-value \\
\hline $\begin{array}{l}\text { SBP before physio- } \\
\text { therapy }\end{array}$ & vs. & $\begin{array}{l}\text { SBP before physio- } \\
\text { therapy }\end{array}$ & $>0.05$ \\
\hline $\begin{array}{l}\text { SBP after physio- } \\
\text { therapy }\end{array}$ & vs. & $\begin{array}{l}\text { SBP after physio- } \\
\text { therapy }\end{array}$ & $>0.05$ \\
\hline $\begin{array}{l}\text { DBP before physio- } \\
\text { therapy }\end{array}$ & vs. & $\begin{array}{l}\text { DBP before physio- } \\
\text { therapy }\end{array}$ & $>0.05$ \\
\hline $\begin{array}{l}\text { DBP after physio- } \\
\text { therapy }\end{array}$ & vs. & $\begin{array}{l}\text { DBP after physio- } \\
\text { therapy }\end{array}$ & $>0.05$ \\
\hline
\end{tabular}

Values of SBP before and after physiotherapy treatment (treated with inhaled glucocorticoids)

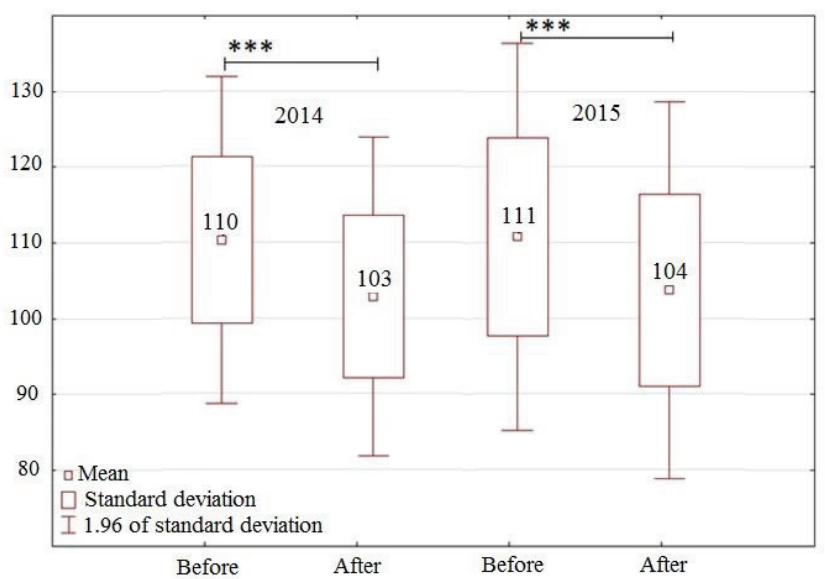

Figure 4. Values of SBP from measurements made in the year 2014 and 2015 (children treated with inhaled glucocorticoids)

$* * * p<0.001$. 


\section{Discussion}

The changes observed in BP seem to be the effect of post exercise hypotension (PEH), defined as a blood pressure decrease after exercise as the result of physical exertion, which is observed after its cessation. The first publications describing this phenomenon were published nearly 50 years ago [7]. The physiological background of this process is not clearly identified, but it is assumed that reduction of peripheral resistance caused by higher secretion of atrial natriuretic peptide (ANP), lower activity of peripheral sympathetic neurons, increased secretion of nitrous oxide and dilatation of peripheral vessels as a response to heat production seem to play the most significant role. Endogenous opioid mediators in the central nervous system and the activity of central serotonergic mechanisms are also indicated as responsible for PEH [8]. Many publications show that PEH is more pronounced among people with hypertension (especially among those with stage 1 hypertension) compared to normotensive individuals $[9,10]$. An interesting fact is that PEH can be achieved by short-lasting and non-intensive effort [11], and it may last up to 16 hours after exercise [9]. All the abovementioned statements were determined by research made among adult individuals, where most of the subjects were middle-aged males with high normal BP or with stage 1 hypertension. An important question is whether the existence of $\mathrm{PEH}$ has an influence on the long-term hypotensive effect or not. This correlation has not been unambiguously confirmed; however, some publications show that it is very likely to exist $[12,13]$.

According to our knowledge, the observation of PEH among children is limited to two research studies conducted on small groups (16 and 10 individuals) [14, 15]. In our study, 240 children were examined, and their BP was taken five times before and after exercise.

Our readings have shown a statistically significant lowering of SBP after the exercises, although the decrease in DBP was not statistically significant. Other publications also show that physical activity has a larger impact on SBP than DBP [8].

Another significant observation is the difference between the average values of SBP measured after the exercises with reference to the control group consisting of 50 children. The aver- age SBP measured in the afternoon on the day which was free of physical effort was $12 \mathrm{~mm} \mathrm{Hg}$ higher compared to the SBP noticed at the same time of day but after physical activity, and the difference concerning DBP was $5.4 \mathrm{~mm} \mathrm{Hg}$. Furthermore, the afternoon SBP in the control group was $11.9 \mathrm{~mm} \mathrm{Hg}$ higher, and DBP was $3.3 \mathrm{~mm} \mathrm{Hg}$ higher compared to the values measured in the morning. Children who were exercising during the day had lower BP in the afternoon than in the morning. According to these results, we can assume that morning exercises performed by children and adolescents not only prevent BP from rising during the day, but also decrease it.

The existence of PEH among normotensive adults was questioned in some research studies. Moreover, some of the studies reported an increase of BP after physical activity [10]. The participants of our rehabilitation treatment camp had some mild respiratory tract disorders, but their $\mathrm{BMI}$, blood pressure and fitness was typical for the Polish population of children between 8 and 15 years of age. Most of the participants were normotensive. According to these facts, we can assume that physical activity has a positive effect on blood pressure among schoolchildren. The duration of PEH in this population and its long-term influence on BP requires further investigation.

The values of $H R$ were not significantly different before and after the exercises, and according to this fact, we can exclude the influence of $\mathrm{HR}$ changes on BP.

Considering the fact that there was no possibility to divide the groups of children who had only cardio exercises without physiotherapy (and vice versa), our research is unable to show the impact of physiotherapy itself on BP.

The intensity of effort was not standardized in our research, which means that our research can only evaluate the effect of rehabilitation generally, without differentiating between it's particular components.

\section{Conclusions}

Rehabilitation procedures provided during rehabilitation summer camp significantly lower SBP in schoolchildren and adolescents with respiratory tract disorders. Post exercise hypotension is noticeable in the group, manifested by a lower SBP after the physical activity.

Source of funding: This work was funded by the authors' resources. Conflict of interest: The authors declare no conflict of interests.

\section{References}

1. Litwin M, Niemirska A. Nadciśnienie tętnicze pierwotne i zaburzenia metaboliczne u dzieci i młodzieży. Forum Zab Metabol 2011; 2(2): 124-131.

2. Kawalec W, Grenda R, Ziółkowska H. Pediatria. Vol. 1. Warszawa: Wydawnictwo Lekarskie PZWL; 2013: 451-452.

3. Kułaga Z, Różdżyńska A, Palczewska, et al. Siatki centylowe wysokości, masy ciała i wskaźnika masy ciała dzieci i młodzieży w Polsce - wyniki badania OLAF. Stand Med, Pediatr 2010; 7: 690-700.

4. Han JC, Lawlor DA, Kimm SY. Childhood obesity. Lancet 2010; 375(9727): 1737-1748.

5. Vos LE, Oren A, Bots ML, et al. Does a routinely measured blood pressure in young adolescence accurately predict hypertension and total cardiovascular risk in young adulthood? J Hypertens 2003; 21(11): 2027-2034.

6. Sun SS, Grave GD, Siervogel RM, et al. Systolic blood pressure in childhood predicts hypertension and metabolic syndrome later in life. Pediatrics 2007; 119(2): 237-246.

7. Kaul J, Chrastek J, Adamirova J. The hypotensive effect of physical activity. In: Rabb W, ed. Prevention of ischemic heart disease: principles and practice. Springfield, IL: Charles C Thomas; 1966: 359-371.

8. Kenney MJ, Seals DR. Postexercise hypotension. Key features, mechanisms, and clinical significance. Hypertension 1993; 22(5): 653-664 .

9. Thompson P, Crouse S, Goodpaster B, et al. The acute versus the chronic response to exercise. Med Sci Sports Exerc 2001; 33(Suppl. 6): S438-S445.

10. Pescatello LS, Fargo AE, Leach CN, et al. Short-term effect of dynamic exercise on arterial blood pressure. Circulation 1991; 83(5): 1557-1561.

11. Guidry MA, Blanchard BE, Thompson PD, et al. The influence of short and long duration on the blood pressure response to an acute bout of dynamic exercise. Am Heart J 2006; 151(6): 1322-1334.

12. Halliwill JR. Mechanisms and clinical implications of post-exercise hypotension in humans. Med Sci Sports Exerc 2001; 29(2): 65-70.

13. Hecksteden A, Grütters T, Meyer T. Association between postexercise hypotension and long-term training-induced blood pressure reduction: a pilot study. Clin J Sport Med 2013; 23(1): 58-63. 
14. Rauber SB, Boullosa D, Carvalho FO, et al. Traditional games resulted in post-exercise hypotension and a lower cardiovascular response to the cold pressor test in healthy children. Front Physiol 2014; 5: 235.

15. Duncan MJ, Clarke ND, Birch SL, et al. The effect of 'green exercise' on post exercise hypotension in children. Appetite 2014; 76: 199.

Tables: 5

Figures: 4

References: 15

Received: 03.02.2016

Revised: 12.02 .2016

Accepted: 14.03.2016

Address for correspondence:

Iwona Pirogowicz, MD, PhD

Katedra i Klinika Geriatrii UM

ul. M. Skłodowskiej-Curie 66

50-369 Wrocław

Polska

Tel.: +48 71 784-25-21

E-mail: iwona.pirogowicz@umed.wroc.pl 